\title{
The Benefits and Uses of Red Dragon Fruit in Food Consumption
}

\author{
Widya Hary Cahyati ${ }^{1}$, Natalia Desy Putriningtyas ${ }^{2}$ \\ \{widyahary27@mail.unnes.ac.id ${ }^{1}$, nataliadesy@mail.unnes.ac.id ${ }^{2}$ \} \\ Universitas Negeri Semarang, Indonesia ${ }^{12}$
}

\begin{abstract}
Red dragon fruit is a fruit that contains a lot of benefits. Dragon fruit can be consumed in various forms, such as yogurt, juice, and syrup. This article is a literature review, where the researcher collects several relevant articles, then they are reviewed, analyzed, and discussed systematically, to be able to make conclusions from the analysis. Based on several articles analyzed, it can be concluded that the way to consume the red dragon fruit are to make it into yogurt, fruit juice, syrup, dodol, sticks, jam, juice, candy, and ice cream. Red dragon fruit has positive effects on health, including blood circulation, neutralizes toxins in the blood, prevents cancer, lowering level of fat in the blood, as antioxidant, balancing blood sugar levels, and treats vaginal discharge.
\end{abstract}

Keywords: Red Dragon Fruit, Processed Foods, Fiber, Thrombocyte, Antioxidants.

\section{Introduction}

Indonesia is a country that has a tropical climate. In addition, land in Indonesia is fertile and has abundant natural resources. The soil fertility and good climate factors make Indonesia to be one of the countries that has tremendous potential in the fields of agriculture, plantations, forests, and matters related to farming. Because of Indonesia is one of the countries with a tropical climate, so it has the potential to produce typical fruits that grow in the tropics. One of the fruits that can thrive in tropical areas is dragon fruit [1]. Dragon fruit is a fruit that has oval shape or slightly round. It has skin with dragon-like, and has a red color. There is also dragon fruit which has yellow skin. Because of this fruit has fins similar to a dragon, so it known as the dragon fruit [2].

Dragon fruit is a fruit that is very suitable to be cultivated in areas that have tropical climates. Dragon fruit has many benefits, one of which is to improve blood circulation, reduce plaque, and also neutralize toxins in the blood. In addition, other benefits of dragon fruit are to prevent colon cancer and reduce levels of fat in the blood. Based on the results of the study, dragon fruit contains many nutrients, including flavonoids, polyphenols, and $\mathrm{C}$ vitamins which is quite high, where $\mathrm{C}$ vitamins is effective as an antioxidant, even though each dragon fruit species has different nutritional levels. Apart from the fruit, dragon fruit skin is also very useful, including as a natural dye for food and beverages. In the world of health, dragon fruit peel can be used as herbal medicine which has natural antioxidant properties [3]. This is supported by Rakhmadhan \& Riki's research which states that the red dragon fruit peel extract with a concentration of 1 gram can provide a percentage of antioxidant activity of $20.867 \%$ with an IC value of 3.14 grams / 100ml or $31.040 \mathrm{ppm}$. Rakhmadhan \& Riki's research proves that red dragon fruit skin has potential as an antioxidant, because based on their research, dragon fruit peel has antioxidant activity, where super dragon fruit peel waste has higher antioxidant 
compounds compared to ordinary red dragon fruit peel [1]. So far, the skin of dragon fruit has been underutilized by the community, and has only been disposed of as waste.

\section{Methods}

This article is a literature review, where the researcher collects several relevant articles, then they are reviewed, analyzed, and discussed systematically, to be able to make conclusions from the analysis. In conducting article searches, researchers used google scholar, with the keyword "Dragon Fruit". At the first stage search, 516 articles were found. Then the researchers narrowed the scope of time, by selecting articles published in 2016-2021. From this second stage search, there were 53 articles. From the 53 articles, the researchers manually selected articles that discussed the use of dragon fruit in food consumption, and obtained 25 articles. Then the researchers sorted the articles based on the quality of the articles. The final step, the researcher reviews, analyzes, and synthesizes the article to make conclusions from the analysis.

\section{$3 \quad$ Result and Discussion}

After researchers browsed through several research articles on the utilization of dragon fruit and dragon fruit parts, we synthesized and analyzed some of these articles. One of the articles we analyzed was an article written by Rakhmadhan \& Riki, who examined super quality red dragon fruit skin extract as an antioxidant using the DPPH method to determine \% antioxidant activity and IC50 in super red dragon fruit peel extract grown in South Kalimantan. This study aims to determine the $\%$ antioxidant activity and the IC50 value contained in the super red dragon fruit peel extract. This research was conducted using a spectophotometric technique with DPPH reagent on viscous extracts which were divided into several concentrations, namely $1 \%$, $0.5 \%, 25 \%, 0.125 \%$, and $0.0625 \%$. Measurement of antioxidant activity is measured until IC50 is obtained by entering the $y$ value $(y=50)$ in the line equation $y=b x+a$. Based on the results of Rakhmadhan \& Riki's research, it was found that the greatest \% activity value was at a concentration of $1 \%$, which was $36.73 \%$, while the lowest $\%$ activity value was at a concentration of $0.0625 \%$ which was $10.48 \%$. The IC50 value obtained was $1.583 \%$ or 15,830 ppm with a very weak category of antioxidant activity. Even though it is very weak, we can say that in the super red dragon fruit peel extract grown in the plantation of Tajau Pecah Village, Tanah Laut Regency, there is antioxidant activity [4]. Based on field observations, dragon fruit peels constitute thirty-five percent of the total dragon fruit parts. It can be said that dragon fruit culture is a byproduct that has not been used optimally and in society it is usually only thrown into garbage or waste, even though dragon fruit skin actually has large levels of flavonoids such as fruit flesh which can be used as antioxidants [5]. 
Table 1. Research about the benefits of dragon fruit

\begin{tabular}{|c|c|c|}
\hline Authors & Title & Result \\
\hline Rakhmadhan & Uji Aktivitas Antioksidan Ekstrak & There is antioxidant activity in the super \\
\hline $\begin{array}{l}\text { Niah, } \quad \text { Riki } \\
\text { Nirwan } \\
\text { Baharsyah }\end{array}$ & $\begin{array}{l}\text { Etanol Kulit Buah Naga Merah Super } \\
\text { (Hyclocereus costaricencis) }\end{array}$ & $\begin{array}{l}\text { red dragon fruit peel extract grown in the } \\
\text { plantation of Tajau Pecah Village, Tanah } \\
\text { Laut Regency }\end{array}$ \\
\hline Hernawati, N A & The Role of Red Dragon Fruit Peel & Dragon fruit skin has large levels of \\
\hline Setiawan, & (Hylocereus & flavonoids which can be used as \\
\hline $\begin{array}{l}\text { Shintawati, } \\
\text { Priyandoko }\end{array}$ & $\begin{array}{l}\text { Improvement Blood Lipid Levels of } \\
\text { Hyperlipidaemia Male Mice }\end{array}$ & antioxidants \\
\hline Rofiatun & Analisis Kadar Vitamin C pada Selai & Dragon fruit has great benefits for health \\
\hline $\begin{array}{lr}\text { Nisa, } & \text { Hari } \\
\text { Santoso, Ahmad } \\
\text { Syauqi }\end{array}$ & $\begin{array}{l}\text { Stroberi (Fragaria sp.) - Buah Naga } \\
\text { (Hylocereus costaricensis) }\end{array}$ & $\begin{array}{l}\text { to balance blood sugar levels, preventing } \\
\text { diabetes and colon cancer, and reduce } \\
\text { cholesterol levels in the body }\end{array}$ \\
\hline Reni Heryani. & $\begin{array}{l}\text { Pengaruh Ekstrak Buah Naga Merah } \\
\text { Terhadap Profil Lipid Darah Tikus } \\
\text { Putih Hiperlipidemia }\end{array}$ & $\begin{array}{l}\text { Dragon fruit can be processed into various } \\
\text { processed products including fruit juice, } \\
\text { syrup, jam, dodol, sticks, jam, and ice } \\
\text { cream }\end{array}$ \\
\hline M. Ilmi Hidayat, & Taga Sebagai & Dragon fruit can be made into various \\
\hline Inda Ilma Ifada, & ilai Tambah & hamely \\
\hline Khairu & Dan Pengendalian Harga Buah Naga & various dragon fruit snacks, dragon fruit \\
\hline Ni'mah & Di Kabupaten Tanah Laut & $\begin{array}{l}\text { juice, dragon fruit sticks, dragon fruit jam, } \\
\text { and dragon fruit ice cream }\end{array}$ \\
\hline Nia Rochmawati & $\begin{array}{l}\text { Utilization of Red Dragon Fruit } \\
\text { (Hylocereus polyrhizus) Peel as } \\
\text { Flour for Making Cookies }\end{array}$ & $\begin{array}{l}\text { The content of crude food fiber in red } \\
\text { dragon fruit is } 10.1 \text { grams per } 100 \text { grams. } \\
\text { The content of vitamins A, C and } \mathrm{E} \text { in this } \\
\text { fruit were } 102.13 \mu \mathrm{g}, 540.27 \mu \mathrm{g} \text { and } \\
105.67 \mu \mathrm{g} \text { per } 100 \text { grams of dry weight. } \\
\text { Red dragon fruit is usually consumed } \\
\text { directly or processed as juice, candy, ice } \\
\text { cream, syrup, and so on }\end{array}$ \\
\hline $\begin{array}{l}\text { Suci Nur Nur } \\
\text { Laxmi, }\end{array}$ & $\begin{array}{l}\text { Pengaruh Filtrat Kulit Buah Naga } \\
\text { Merah (Hylocereus polvrhizus) }\end{array}$ & $\begin{array}{l}\text { The skin of white dragon fruit was used } \\
15 \% \text { as a substitute for wheat flour. The }\end{array}$ \\
\hline Tjandrakirana & terhadap Kadar Glukosa Darah & dragon fruit peel will affect the fiber, ash, \\
\hline Tjandrakirana, & Mencit Mus Musculus) yang & and carbohydrate content of the cookies. \\
\hline Nur Kuswanti & Diinduksi Glukosa & $\begin{array}{l}\text { The protein, fat, ash, and fiber content of } \\
\text { the red dragon fruit skin were } 8.98 \% \text {, } \\
2.60 \%, 18.76 \% \text { and } 25.56 \%\end{array}$ \\
\hline $\begin{array}{l}\mathrm{Ni} \text { Made Indah } \\
\text { Ayuni }\end{array}$ & $\begin{array}{l}\text { Efek Buah Naga Merah (Hylocereus } \\
\text { polyrhizus) Terhadap Penurunan } \\
\text { Kadar Glukosa Darah Pada Diabetes } \\
\text { Tipe } 2\end{array}$ & $\begin{array}{l}\text { The red dragon fruit has benefits for } \\
\text { lowering blood glucose levels }\end{array}$ \\
\hline $\begin{array}{l}\text { Kresto Ratimba, } \\
\text { Valen Ruterlin, } \\
\text { Joni Tandi }\end{array}$ & $\begin{array}{l}\text { Uji Aktivitas Fraksi Buah Naga } \\
\text { Merah Terhadap Penurunan Glukosa } \\
\text { Darah Tikus yang Diinduksi } \\
\text { Streptozotocin }\end{array}$ & $\begin{array}{l}\text { Red dragon fruit (Hylocereus polyrhizus) } \\
\text { is believed to balance blood glucose levels }\end{array}$ \\
\hline $\begin{array}{lr}\text { Yuska } & \text { Novi } \\
\text { Yanty, } & \text { Vetria } \\
\text { Ade Siska } & \end{array}$ & $\begin{array}{l}\text { Ekstrak Kulit Buah Naga Merah } \\
\text { (Hylocereus polyrhizus) Sebagai } \\
\text { Antioksidan dalam Formulasi } \\
\text { Sediaan Lotion }\end{array}$ & $\begin{array}{l}\text { Dragon fruit has a fairly high antioxidant } \\
\text { content, including flavonoid compounds, } \\
\text { vitamin C, and polyphenols. In addition, } \\
\text { dragon fruit also has color pigments in the } \\
\text { form of anthocyanins which also function } \\
\text { as antioxidants }\end{array}$ \\
\hline
\end{tabular}




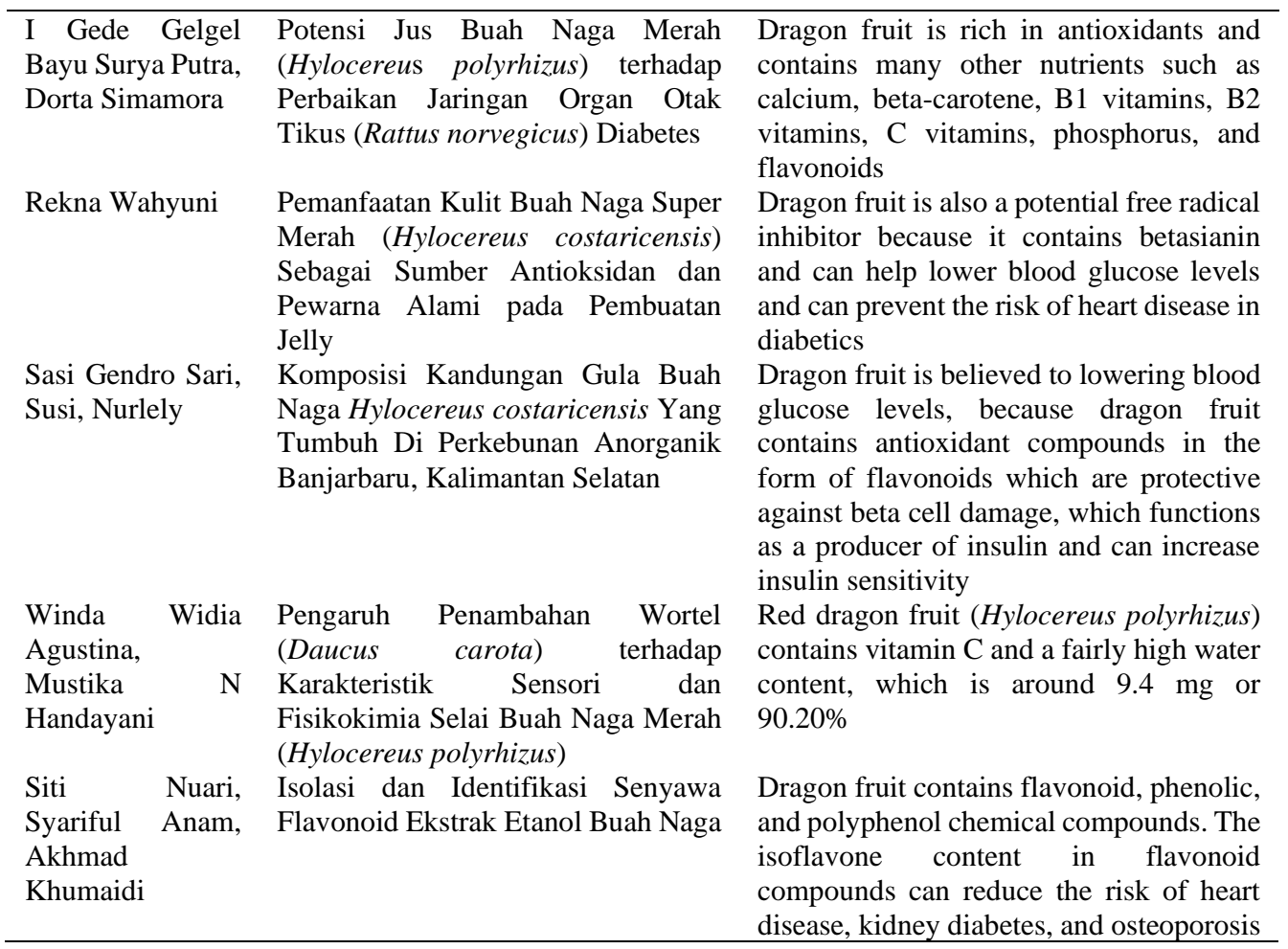

Increasing public knowledge about the use of dragon fruit can also be found in an article written by Ilmi Hidayat et al, where in the article, namely about dragon fruit processing as an effort to increase added value and control the price of dragon fruit in Tanah Laut Regency, explained that in South Kalimantan, cultivation Dragon fruit only started in 2007. The types of dragon fruit grown are mainly red dragon fruit. At first the people were not familiar with dragon fruit, but because of its sweet and fresh taste, and its benefits are quite high, so that this red dragon fruit is increasingly known in the community. The increasing public interest in dragon fruit has led to an increasing trend of dragon fruit cultivation [6]. In addition, dragon fruit cultivation is technically quite easy to develop, because dragon fruit plants can grow in any soil and altitude. The thing to note is that this plant is quite greedy for nutrients, so that if it is planted in soil that contains good fertilizer, it will grow well. According to research, dragon fruit has great benefits for health, namely being able to balance blood sugar levels, preventing diabetes and colon cancer, and being able to reduce cholesterol levels in the body [7].

The cultivation of dragon fruit, which is getting more and more, causes the stock of dragon fruit is also quite a lot. This is detrimental to the farmers because the price is decreasing. This happens because many cultivate plant dragon fruit, but there is no further processing. This of course will be detrimental to farmers, so to overcome this problem it is necessary to design an appropriate post-harvest handling strategy from upstream to downstream so that farmers are not harmed. Apart from being marketed in fresh form, dragon fruit can also be processed into various processed products including fruit juice, syrup, jam, dodol, sticks, jam, and ice cream. Dragon fruit peel which weighs about $30-35 \%$ of the weight of the fruit with a red color with certain techniques can be processed into functional drinks, namely as a source of antioxidants that are useful for health and can be used as natural dyes. The business opportunity for dragon 
fruit processed products is still wide open because dragon fruit has several advantages compared to other fruits, namely having properties that are beneficial to human health, including as a balancing of blood sugar levels, protecting oral health, preventing colon cancer, reducing cholesterol, preventing bleeding, and treating complaints of vaginal discharge, so that dragon fruit processed products can be used as functional food [8] [9].

In the article written by Ilmi Hidayat et al., it is known that the problems in the community are: 1 . Not having skills and knowledge to increase added value in the form of processed dragon fruit products; 2 . The price of dragon fruit and farmers' income continues to decline while the number of farmers cultivating it is increasing; 3 . The need for innovation development in order to sustain their business and increase their income; 4 . The absence of sufficient business capital and tools to make processed food products from dragon fruit. Based on these community problems, dragon fruit processing training activities were held by making several tiger products made from dragon fruit as raw material and business management training. The results of these activities indicate that: 1) Dragon fruit can be made into various kinds of processed products, namely various dragon fruit snacks, dragon fruit juice, dragon fruit sticks, dragon fruit jam, and dragon fruit ice cream; 2) Based on the level of consumer acceptance, processed dragon fruit products range from 'like' level to 'very like' for color and 'like' level for taste, aroma, and overall [6].

Based on the article from Nia Rochmawati, it is stated that dragon fruit, which is a cactus species, consists of red dragon fruit (Hylocereus polyrhizus), white dragon fruit (H. undatus), and yellow dragon fruit (Selenicereus megalanthus) [10]. Red dragon fruit has a high water and fiber content. The content of crude food fiber in red dragon fruit is 10.1 grams per 100 grams. In addition, the content of vitamins $\mathrm{A}, \mathrm{C}$ and $\mathrm{E}$ in this fruit were $102.13 \mu \mathrm{g}, 540.27 \mu \mathrm{g}$ and $105.67 \mu \mathrm{g}$ per 100 grams of dry weight, respectively. Red dragon fruit is usually consumed directly or processed as juice, candy, ice cream, syrup, and so on. While the by-product in the form of skin as much as $22 \%$ of the red dragon fruit is just thrown away. Red dragon fruit skin contains pectin, betasianin pigment, and dietary fiber with a soluble dietary fiber: insoluble dietary fiber ratio of 1:3.8. A research on the use of cookies from white dragon fruit peel has been conducted by Suci et al. In that study, it was stated that the skin of white dragon fruit was used as much as $15 \%$ as a substitute for wheat flour. The results obtained indicate that the addition of dragon fruit peel will affect the fiber, ash, and carbohydrate content of the cookies. The protein, fat, ash, and fiber content of the red dragon fruit skin were $8.98 \%, 2.60 \%, 18.76 \%$ and $25.56 \%$, respectively. Dietary fiber is a part of carbohydrates that cannot be digested by the body [11]. Dietary fiber is categorized into two based on its solubility in water, namely soluble dietary fiber and insoluble dietary fiber. The average adult fiber requirement is $30 \mathrm{~g} / \mathrm{d}$ [12]. A food can be claimed as a source of fiber if it meets $3 \mathrm{~g} / 100 \mathrm{~g}$ of solid weight of a food. Based on the article from Nia Rochmawati, it was found that dragon fruit skin cookies from a chemical perspective were obtained from the proportion of dragon fruit skin flour: wheat flour (90:10) had a water content of $8.06 \%$, an ash content of $6.81 \%$, a protein content of $5.63 \%$, a fat content of $27.03 \%$, carbohydrate content of $52.47 \%$, and fiber content of $31.26 \%$. Each serving also meets several requirements required as standard quality cookies except for water content standards [10].

Based on research from Ni Made Indah Ayuni, red dragon fruit is easy to find in various regions and tastes sweet. This causes dragon fruit to be very popular with the community. In addition to its delicious taste, red dragon fruit also has benefits for lowering blood glucose levels, so Ni Made Indah Ayuni wants to research the effect of red dragon fruit in reducing blood glucose levels in people with type 2 diabetes mellitus [13]. According to Kresto Ratimba, one of the traditional medicinal plants that can be used by the community is red dragon fruit 
[14]. This is because red dragon fruit (Hylocereus polyrhizus) is believed to balance blood glucose levels. Red dragon fruit (Hylocereus polyrhizus) is a plant that comes from dry tropical climates. Dragon fruit has a fairly high antioxidant content, including flavonoid compounds, vitamin $\mathrm{C}$, and polyphenols. In addition, dragon fruit also has color pigments in the form of anthocyanins which also function as antioxidants [15]. Dragon fruit is rich in antioxidants and contains many other nutrients such as calcium, beta-carotene, B1 vitamins, B2 vitamins, C vitamins, phosphorus, and flavonoids [16]. Dragon fruit is also a potential free radical inhibitor because it contains betasianin and can help lower blood glucose levels and can prevent the risk of heart disease in diabetics [17]. Based on research, dragon fruit is believed to have the effect of lowering blood glucose levels, because dragon fruit contains antioxidant compounds in the form of flavonoids which are protective against beta cell damage, which functions as a producer of insulin and can increase insulin sensitivity [18]. The way flavonoids work is by inhibiting the absorption of glucose in GLUT-2 and causing the major glucose transporter in the intestine to decrease, causing the glucose level in the blood to also decrease. It can be said that the flavonoids contained in dragon fruit can also prevent diabetes mellitus. Dragon fruit also contains high fiber which is important for digestive health. Dragon fruit also contains lycopene compounds, which are pigments that give red color. The function of lycopene can affect insulin hormone resistance, so that it can cause the body's tolerance to glucose to increase [19]. The fiber contained in dragon fruit can bind water, so that glucose is less likely to come in contact with the intestinal wall and enter the blood. This causes the pancreas to produce less insulin, because the level of glucose that enters the blood is low, resulting in a decrease in glucose levels in the blood [20].

Based on the research, it is known that the effect of dragon fruit with higher doses will have a tendency to decrease blood glucose is greater for people with type 2 diabetes mellitus. This is in line with research conducted by Siti, that red dragon fruit contains many bioactive compounds that have potential as anti-free radicals, for example betasianin [7]. In addition, according to Kristanto, 2013, red dragon fruit (Hylocereus polyrhizus) also contains vitamin C and a fairly high water content, which is around $9.4 \mathrm{mg}$ or $90.20 \%$ [21]. Dragon fruit contains flavonoid, phenolic, and polyphenol chemical compounds. According to Asih, 2012, the content of flavonoid compounds in red dragon fruit can reduce glucose levels in the blood. In addition, the isoflavone content in flavonoid compounds can also reduce the risk of heart disease, kidney diabetes, and osteoporosis [22].

\section{Conclusion}

Based on the discuss above, it can be concluded that dragon fruit can be consumed directly in fresh form, or processed in various forms, including yogurt, fruit juice, syrup, dodol, sticks, jam, juice, candy, and ice cream. Dragon fruit peel can be processed into functional drinks. The benefits of consuming dragon fruit are to improve blood circulation, reduce emulsions, and neutralize toxins in the blood, prevent colon cancer and reduce fat levels in the blood. In addition, dragon fruit also contains antioxidants, balances blood sugar levels, prevents diabetes and colon cancer, lowers cholesterol levels in the body, protects oral health, prevents bleeding and treats vaginal discharge complaints. Dragon fruit is proven to be able to reduce blood glucose levels in people with type 2 diabetes mellitus, preventing the risk of heart disease, kidney diabetes, and osteoporosis. The nutrients contained in dragon fruit include calcium, betacarotene, B1 vitamins, B2 vitamins, C vitamins, phosphorus, flavonoids, phenolic, and polyphenols. In addition, dragon fruit skin can also be used as a natural dye for food and beverages, natural antioxidants, and ingredients for making cookies. 


\section{References}

[1] Rakhmadhan Niah, Riki Nirwan Baharsyah. Uji Aktivitas Antioksidan Ekstrak Etanol Kulit Buah Naga Merah Super (Hyclocereus costaricencis). Jurnal Pharmascience. 2018; 5(1): 14-21.

[2] Widya Hary Cahyati, Natalia Desy Putriningtyas. Dosis Efektif Yogurt Kulit Buah Naga Merah Untuk Meningkatkan Trombosit. Pemanfaatan Sumber Daya Alam Indonesia: Ketahanan pangan, Energi dan Material Maju. 2021. Unnes. DOI:https://doi.org/10.15294/pemanfaatansdaindonesia. v0i0.2.

[3] Norhayati Abd Hadi, Marhazlina Mohamad, Mohd Adzim Khalili Rohin, Rokiah Mohd Yusof. 2016. Effects of Red Pitaya Fruit (Hylocereus polyrhizus) Consumption on Blood Glucose Level and Lipid Profile in Type 2 Diabetic Subjects. Borneo Science. 2016; 31: 127-142.

[4] Rakhmadhan Niah, Riki Nirwan Baharsyah. Aktivitas Antioksidan Ekstrak Etanol Kulit Buah Naga Merah Daerah Pelaihari, Kalimantan Selatan Dengan Metode DPPH (2,2-difenil-1-pikrilhidrazil). Jurnal Pharmascience. 2016; 3(2): 36-42.

[5] Hernawati, N A Setiawan, R Shintawati, D Priyandoko. The Role of Red Dragon Fruit Peel (Hylocereus polyrhizus) to Improvement Blood Lipid Levels of Hyperlipidaemia Male Mice. Journal of Physics. 2018: 1013.

[6] M. Ilmi Hidayat, Inda Ilma Ifada, Gusti Khairu Ni'mah. IbM Pengolahan Buah Naga Sebagai Upaya Meningkatkan Nilai Tambah Dan Pengendalian Harga Buah Naga Di Kabupaten Tanah Laut. Jurnal Al-Ikhlas. 2018; 3(2): 163-167.

[7] Siti Rofiatun Nisa, Hari Santoso, Ahmad Syauqi. Analisis Kadar Vitamin C pada Selai Stroberi (Fragaria sp.) - Buah Naga (Hylocereus costaricensis). Jurnal Sains Alami (Known Nature). 2020; 2(2): 1-7.

[8] Reni Heryani. Pengaruh Ekstrak Buah Naga Merah Terhadap Profil Lipid Darah Tikus Putih Hiperlipidemia. Jurnal Ipteks Terapan, 2016; 10(1): 26-34.

[9] Rochmanah Suhartati. Aktivitas Antibakteri Ekstrak Etanol Kulit Buah Naga Merah (Hylocereus polyrhizus) Terhadap Bakteri Streptococcus pyogenes. Jurnal Kesehatan Bakti Tunas Husada. 2017; 17(2): 513-518.

[10] Nia Rochmawati. Utilization of Red Dragon Fruit (Hylocereus polyrhizus) Peel as Flour for Making Cookies. Jurnal Pangan dan Agroindustri. 2019; 7(3): 19-24.

[11] Suci Nur Nur Laxmi, Tjandrakirana Tjandrakirana, Nur Kuswanti. Pengaruh Filtrat Kulit Buah Naga Merah (Hylocereus polyrhizus) terhadap Kadar Glukosa Darah Mencit Mus Musculus) yang Diinduksi Glukosa. LenteraBio, 2017; 6(1): 1-5.

[12] Betrik Sefyana Mangiri, Sinar Yani, Silvia Anitasari. Sari Buah Naga Super merah (Hylocereus costaricensis) Sebagai Pewarna Alami Plak Gigi. Jurnal Material Kedokteran Gigi. 2018; 7(1): 2834.

[13] Ni Made Indah Ayuni. Efek Buah Naga Merah (Hylocereus polyrhizus) Terhadap Penurunan Kadar Glukosa Darah Pada Diabetes Tipe 2. Jurnal Ilmiah Kesehatan Sandi Husada. 2020; 9(1): 566-572.

[14] Kresto Ratimba, Valen Ruterlin, Joni Tandi. Uji Aktivitas Fraksi Buah Naga Merah Terhadap Penurunan Glukosa Darah Tikus yang Diinduksi Streptozotocin. Farmakologika. 2019; XVI(1): 3547.

[15] Yuska Novi Yanty, Vetria Ade Siska. Ekstrak Kulit Buah Naga Merah (Hylocereus polyrhizus) Sebagai Antioksidan dalam Formulasi Sediaan Lotion. Jurnal Ilmiah Manuntung, 2017; 3(2): 166172.

[16] I Gede Gelgel Bayu Surya Putra, Dorta Simamora. Potensi Jus Buah Naga Merah (Hylocereus polyrhizus) terhadap Perbaikan Jaringan Organ Otak Tikus (Rattus norvegicus) Diabetes. Jurnal Ilmiah Kedokteran. 2019; 8(2): 84-95.

[17] Rekna Wahyuni. Pemanfaatan Kulit Buah Naga Super Merah (Hylocereus costaricensis) Sebagai Sumber Antioksidan dan Pewarna Alami pada Pembuatan Jelly. Teknologi Pangan : Media Informasi Dan Komunikasi Ilmiah Teknologi Pertanian, 2011; 2(1): 68-85.

[18] Sasi Gendro Sari, Susi, Nurlely. Komposisi Kandungan Gula Buah Naga Hylocereus costaricensis Yang Tumbuh Di Perkebunan Anorganik Banjarbaru, Kalimantan Selatan. Borneo Jurnal Pharmascientech, 2017; 1(2): 1-9. 
[19] Nunung Setyani, Ni Ketut Sri Sulendri, Fifi Lutfiah, Suhema Suhaema. Pengaruh Pemberian Puding Susu Buah Naga Merah (Hylocereus polyrhizus) Terhadap Kadar Glukosa Darah Puasa Pasien Diabetes Mellitus Tipe 2. Jurnal Gizi Prima (Prime Nutrition Journal). 2019; 4(2),142-155.

[20] Amalia Nita Widyastuti, Etika Ratna Noer. Pengaruh Pemberian Jus Buah Naga Merah (Hylocereus Polyrhizus) Terhadap Kadar Glukosa Darah Puasa Pria Prediabetes, Journal of Nutrition College. 2015; 4(2): 126-132.

[21] Winda Widia Agustina, Mustika N Handayani. Pengaruh Penambahan Wortel (Daucus carota) terhadap Karakteristik Sensori dan Fisikokimia Selai Buah Naga Merah (Hylocereus polyrhizus). Edufortech. 2016; 1(1): 16-28.

[22] Siti Nuari, Syariful Anam, Akhmad Khumaidi. Isolasi dan Identifikasi Senyawa Flavonoid Ekstrak Etanol Buah Naga. Galenika Journal of Pharmacy, 2017; 2(2), 118-125. 